\title{
Trend Analysis of the Contribution of Agriculture to the Gross Domestic Product of Nigeria (1960 - 2012).
}

\author{
Ahungwa, G.T*; U. Haruna and Rakiya Y. Abdusalam \\ Department of Agricultural Economics and Extension, Federal University Dutse, PMB 7156, Dutse, Jigawa \\ State, Nigeria
}

\begin{abstract}
This study examined the pattern and contribution of agriculture to the Gross Domestic Product (GDP) of Nigeria within a time frame of 53 years (1960-2012). Time-series data emanating from National Bureau of Statistic (NBS), Central Bank of Nigeria, National Planning Commission (NPC) and CIA Factbook were used and analysed using trend and regression analysis. The results showed that the share of agriculture to the total GDP had a downward trend, yet maintaining a clear dominance over other sectors from 1960-1975. Further analysis depicted an undulating trend, intertwining with the industrial sector from 1976-1989. The regression results showed that agriculture has a positive relationship with GDP and contributes significantly with a coefficient of 0.664, implying that a percentage increase in the contribution of agriculture can increase the GDP by 66.4 percent higher than any other sector. This cumulative effect of agriculture on GDP clearly affirmed the dominance of the sector's contribution to the GDP of Nigeria. The study therefore recommended that government should create an enabling environment by increasing the budgetary allocation, friendly policies framework for strong and efficient agricultural sector that can accelerate the attainment of Nigeria's dream of achieving the targeted growth rate and the proposed vision of becoming one among the 20 leading world economies by the year 2020.
\end{abstract}

Keywords: Trend analysis, Agriculture, Gross Domestic Product, Nigeria.

\section{Introduction:}

The Transformation Agenda of the present administration identified seven sectors as the main growth drivers during the transformation period, 2011-2015, viz: agriculture, water resources, solid minerals, manufacturing, oil and gas, trade and commerce as well as culture and tourism. The decision was prompted by the fact that the performance in these sectors has been constrained by several challenges including low productivity, low level of private sector investment, non-competitiveness, inadequate funding, shortage of skilled manpower, low investment in research and development, poor development of value chain and low value addition, poor regulatory environment, poor quality of goods and services and poor state of physical infrastructure, policy instability and discontinuity, low level of technology, paucity and poor flow of information and high cost of doing business (FGN, 2011). Government thus, assumed a baseline Gross Domestic Product (GDP) growth rate of 11.7 per cent per annum within the period, which will translate to real and nominal GDP of about N428.6 billion and N73.2 trillion, respectively at the end of the programme period.

In recent decades, the potential contribution of agriculture as one of the drivers of economic growth has been a subject of much controversy among development economists. While some contend that agricultural development is a pre-condition for industrialization, others strongly disagree and argue for a different path.

However, the role of agricultural sector in bringing about economic growth and sustainable development of a nation cannot be underestimated. Okolo (2004) described agricultural sector as the most important sector of the Nigeria's economy which holds a lot of potentials for the future economic development of the nation as it had done in the past. Notwithstanding the enviable position of the oil sector in the Nigerian economy over the past three decades, the agricultural sector is arguably the most important sector of the economy. Abayomi (1997) once averred that the stagnation in agriculture is the principal explanation for poor economic performance, while rising agricultural productivity has been the most important concomitant of successful industrialization. Thus, it is not an overstatement to assert that the growth and development of Nigeria depend to a large extent on the development of the agricultural sector.

Statement of the Problem: Available literature reported that in spite of Nigeria's rich agricultural resource endowment; there has been a gradual decline in agriculture's contributions to the nation's economy (Manyong et al., 2005;Ekpo and Umoh, 2012; Mohammad and Atte, 2006) as evident in the contribution of agriculture to the GDP of the nation as well as the rising value of food import (CBN, 2010).

This development prompted government to initiate several agricultural policies/projects and programmes to enhance agricultural productivity in Nigeria; the establishment of River Basins and Rural Development Authorities, the Agricultural Development Programmes, ADP, over 20 Agricultural Research 
Institutes, Operation Feed the Nation (OFN), Green Revolution, presidential initiatives in 2004-2005, prominent among which was the cassava projects, the 7-Point Agenda with emphasis on Food security, and the recent Agricultural Transformation Agenda of the present administration. Despite all the aforementioned policies and programmes, the performance of the Agricultural sector in Nigeria is abysmal in terms of product contribution, factor contribution, market contribution and foreign exchange contribution (Ehigiamusoe, 2012) as well as rising value of food import.

It is in this light that this study seeks to examine the trend of agricultural sector's contribution to the nation's GDP; assess the impact of agriculture to the nation's economy and trace the associated causes of the trend over the years, and at the same time, suggest policy recommendations expected to bring back the lost glory of the agricultural sector in the country.

Conceptual and Empirical Issues: Agriculture is the economic mainstay of the majority of households in Nigeria (Udoh, 2000) and is a significant sector in Nigeria's economy. The important benefits of the agricultural sector to Nigeria's economy include: the provision of food, contribution to the gross domestic product, provision of employment, provision of raw materials for agro-allied industries, and foreign exchange earnings(Oni et al., 2009).

The advent of oil in the early 1970s made Nigeria highly dependent on oil revenue, with the performance of the agricultural sector adversely affected over the years. Though, the growth rate in the agricultural sector in Nigeria increased from an average of about 3 percent in the 1990s to about 7 percent in mid-2000, certain performance indicators such as food security/sufficiency status of Nigerians continued to decline.

Anyanwu, et al (2013) examined the structure and growth of the GDP over the 49 years of the nation's existence, using multiple regression analysis and discovered that agriculture was among the key significant determinant of Nigeria's GDP with clear dominance from 1960-1984. This dominance is attributed to the fact that agricultural and macroeconomic policies of various governments then were skewed towards massive crop production.

Umaru and Zubairu (2012) made a comparative analysis of the contribution of agriculture and petroleum sectors to the growth and development of Nigerian economy (1960-2010) and the results revealed that agricultural sector contributed higher than the petroleum sector, though they both possessed a positive impact on economic growth and development of the economy. They affirmed that good performance of an economy in terms of per capita growth may therefore be attributed to a well-developed agricultural sector capital. In the same vein, Suleiman and Aminu (2010) conducted research on the contribution of agriculture, petroleum and manufacturing sector of the Nigerian economy and found out that agricultural sector is contributing higher than both petroleum and manufacturing sectors. Their study reveals that agriculture is contributing 1.7978 units to GDP while petroleum is contributing 1.14 units to GDP, which is less than the contribution of agriculture.

The contribution of agricultural sector on the Nigerian economic development as examined by Oji-Okoro (2011) revealed that foreign direct investment (FDI) on agriculture contributes the most (56.43) in terms of agricultural development. This means that for every unit of change in FDI on agriculture there is a corresponding change of 56.43 units in GDP in Nigeria.Ekpo and Umoh (2012)revealed that the contribution of agriculture to GDP, which was 63 percent in 1960, declined to 34 percent in 1988, not because the industrial sector increased its share but due to neglect of agriculture sector. It was therefore not surprising that by 1975 , the economy had become a net importer of basic food items. The apparent increase in industry and manufacturing from 1978 to 1988 was due to activities in the mining sub-sector, especially petroleum.

Muhammad and Atte(2006) analysed agricultural production in Nigeria and revealed that the negative coefficient of the value (-0.07) of the food imports indicates that as food import increases, domestic agricultural production decreases. This might be due to the fact that food importation exposes the local farmers to unfair competition by foreign producers who usually take advantage of economies of scale in production due to their access to better production technology.

\section{Methodology:}

Source of Data: This study is aimed at taking an in-depth analysis of the trend and contribution of the agricultural sector to the overall Gross Domestic product (GDP) of Nigeria's economy using the time series data within a time span of 53 years (1960-2012) of the nation's existence. The essence of choosing this period is to empirically assess the significance or the extent to which agricultural sector contributes to the GDP despite several years of Government neglect and the renewal of effort towards stabilizing the sector. The data used in the study are the sectoral component shares of the Nigerian GDP, with emphasis on the agricultural sector, expressed in Million Naira (since a single driver of GDP cannot sufficiently explain the GDP of a country). Data were obtained from National Bureau of Statistics and Central Bank of Nigeria Annual report (CBN Statistical Bulletin, 2010); CIA Factbook (2013) and NPC annual report (2012). 
Data Analysis and Model Specification: The study employed the use of various statistical approaches to examine the trend and contribution of the shares of agriculture and other constituent sectors to the Nigeria GDP. Trend analysis: Trend analysis was utilized to compliment findings from regression analysis and also to familiarize with general pattern or trend of the data. Trend analysis was used to spot any pattern or trend, for example, by observing whether the shares of agriculture were trending up, trending down or constant in relation to GDP. The goal was to see if there are any systematic patterns over time.

Regression Analysis: Most time series data are generally not stationary, and the use of time series data has become a controversial and complicated issue. Given this situation and the limited goal of this study, we limit the analysis to regression (Double $\log$ ), using annual data on the component shares of economic sectoral contribution to GDP from 1960 to 2012.

Double_Log Regression analysis: The model is explicitly expressed as:

$\operatorname{LnGDP}=\operatorname{Ln} \propto+b_{1} \operatorname{Ln} X_{1}+b_{2} \operatorname{Ln} X_{2}+b_{3} \operatorname{Ln} X_{3}+b_{4} \operatorname{Ln} X_{4}+b_{5} \operatorname{Ln} X_{5}+\operatorname{Ln\varepsilon }$

Where

$\operatorname{LnGDP}=$ Gross Domestic product (at current basic prices, 1960-2012), $\operatorname{Ln} \propto=$ Intercept, $b_{1}-b_{5}=$ regression coefficients, $\operatorname{Ln} X_{1}=\log$ contribution of Agriculture to GDP, $\operatorname{Ln} X_{2}=\log$ contribution of Industry to GDP, $\operatorname{Ln} X_{3}=$ $\log$ contribution of Building and Construction to GDP, $\operatorname{Ln} X_{4}=\log$ contribution of Wholesale and Retail Trade on GDP, $\operatorname{Ln} X_{5}=\log$ contribution of Services to the GDP, $\operatorname{Ln} \varepsilon=\log$ of white noise error term assumed to be 1 .

\section{Results and Discussion}

Trend analysis results: It could be observed in Table 1 and Figure 1 that the overall share of agriculture to GDP as aggregated on five year basis has a downward undulating trend. The downward trend however was steady from 1960-1975. This observation is consistent with earlier findings by Anyanwu et al (2013) which showed the dominance of agriculture share of GDP from 1960-1979, though at a declining rate. Actual figures showed that the shares of agriculture were $61.65 \%, 53.27 \%$, and 39.69\% between 1960-64, 1965-69, and 197074 respectively. However, there was a sharp decline between $1975-1979$ to $23.80 \%, 31.30 \%$ and $38.12 \%$, between1980-1984 and 1985-1989 respectively.

The dominance of agriculture over the periods could be attributed to the focused regional policies that were based on commodity comparative advantage as observed by Azih(2011). He added that the agricultural sector guaranteed the greater percentage of the food security of the average household within the aforementioned periods, export of cash crops earned 70 and 62.2 percent respectively, of Nigeria's total foreign exchange and contributed 56.7 and 66.4 percent of GDP in 1960 and 1965, respectively. This assertion is in consonance with the observations of Ekundare (1973) who attributed the trend to exportation of crops like cocoa, groundnut, cotton, rubber, palmoil and palm kernel, that accounts for an average of between 65-75\% of Nigeria's foreign exchange earnings and provide the most important source of revenue for the federal as well as state governments through export product and sales taxes.

The dominant position of the agricultural sector in this period of the Nigerian economy was therefore, not in doubt. The abrupt decline from 1970-1979 resulted in the advent of commercial exploitation of oil resources, which turned the trend against agriculture and its downstream industries. The oil boom, heralded an era of decay and decline in agriculture and its overall contribution to the economy, as evidenced by the Dutch Disease. This trend reflects the opinion of the United States Department of State (2005) and Sekumade (2009)that the oil boom era, which resulted in extensive exploration and export of petroleum and its products led to neglect of agriculture and light manufacturing bases in favour of an unhealthy dependence on oil for more than $97 \%$ of export earnings and $80 \%$ federal revenue.

The trend between 1970-1974 periods coincided with the result of the Second National Development Plan (1970-74) which spelt out a more defined approach towards food production as the main nexus of the plan because of the Nigerian civil war which created hardship due mainly to food shortages (Andohol, 2012). But Shimada(1999) criticized this view stating that government's pretense towards agriculture was obvious since real budgetary spending on agriculture was a mere $7.7 \%$ against the $23.1 \%$ expenditure on transportation sector alone. Murio (1989) further affirmed that government chose to rely more on food importation rather than address measures to strengthen the capacity base for food production. In addition, the oil-boom that resulted from the Arab oil embargo on the USA in 1973, affected the agricultural sector adversely as the economy was heavily dependent on oil.

The trend was reversed from 1975-1989 with a sharp increment of 23.8\% to $38.12 \%$. The trend could be attributed to the involvement of Government in direct food production, provision of subsidies to peasant farmers and creation of more commodity boards for various agricultural and food products under policies like Operation Feed the Nation. The sector show of resilience of its share in both aggregate GDP and non-oil GDP continued to increase. Credit flow to the agricultural sector measured by the amount of guaranteed loan that flowed to the sector under the agricultural credit guarantee scheme fund and the total bank credit (N44.2 million in the 1981 - 
85 sub-periods to about 36.5 million in the 1986- 90 sub-periods) to the sector could be attributed to this trend (Azih, 2011).

Within the intervals of 1990-1999, the trend of the sector's contribution to the nation's GDP hovers around $32.55 \%$ to $34.32 \%$ with a growth rate of $4.1 \%$. The relative stable trend could be attributed to the advent of numerous programmes of the then administration ranging from the Directorate of Food and Roads and Rural Infrastructure (DFRRI) that spilled over to the 1990s, to National Agricultural Land Development Authority (NALDA) that spanned the period of 1991-1999.

The advent of democracy in 1999-2009 created a renewed commitment to the agriculture with initiatives like the presidential initiatives on selected commodities, the 7-point agenda, and transformation agenda of the present administration. However, the trend on the average remained at about $34.96 \%$. This could be explained on the basis of the inadequate funding and lack of institutional arrangements for implementation of the initiatives. The initiatives generated interest and production increased however, but there were no concurrent provisions for storage and processing resulting in large postharvest losses and apathy on the side of the farmers (FGN Vision 20:2020, 2009).

Generally, the period from 1990 - 2012 witnessed a change in the pattern of the GDP, with the industrial sector taken the lead. This observation agrees with that made by Anyanwu et al (2013) who averred that the dominance is as a result of the contribution of crude petroleum sub-sector to the GDP of industry.

Table 1: Sectoral Analysis of Nigeria's Gross Domestic product from 1960-2012

\begin{tabular}{|c|c|c|c|c|c|c|c|c|c|c|c|}
\hline \multirow[b]{2}{*}{ Year } & \multirow{2}{*}{$\begin{array}{l}\text { Total } \\
\text { GDP } \\
\text { N'm }\end{array}$} & \multicolumn{2}{|c|}{ Agriculture } & \multicolumn{2}{|l|}{ Industry } & \multicolumn{2}{|c|}{$\begin{array}{l}\text { Building } \\
\text { construction }\end{array}$} & \multicolumn{2}{|c|}{$\begin{array}{l}\text { Wholesale \& Retail } \\
\text { Trade }\end{array}$} & \multicolumn{2}{|l|}{ Service } \\
\hline & & $\begin{array}{l}\text { GDP } \\
\text { N'm }\end{array}$ & $\begin{array}{l}\% \\
\text { Cont' } \\
\mathrm{n}\end{array}$ & GDP N'm & $\begin{array}{l}\% \\
\text { Cont' } \\
\mathrm{n}\end{array}$ & $\begin{array}{l}\text { GDP } \\
\text { N'm }\end{array}$ & $\begin{array}{l}\% \\
\text { Con } \\
\text { t'n } \\
\end{array}$ & $\begin{array}{l}\text { GDP } \\
\text { N'm }\end{array}$ & $\begin{array}{l}\% \\
\text { Cont'n }\end{array}$ & GDP N'm & $\begin{array}{l}\% \\
\text { Cont'n }\end{array}$ \\
\hline $1960-64$ & 2568.4 & 1579.64 & 61.65 & 194.88 & 7.50 & 113.72 & 4.42 & 323.32 & 12.58 & 370.44 & 14.37 \\
\hline $1965-69$ & 3088.58 & 1640.26 & 53.27 & 373.76 & 11.93 & 167.26 & 5.41 & 399.46 & 12.93 & 507.84 & 16.46 \\
\hline $1970-74$ & 9314.62 & 3268.4 & 39.69 & 2566.88 & 25.14 & 691.48 & 6.83 & 1408.48 & 13.44 & 1379.38 & 14.90 \\
\hline 1975-79 & 31233.22 & 7328.64 & 23.8 & 10073.88 & 31.59 & 2736.14 & 8.85 & 6235.28 & 19.80 & 4624.76 & 15.08 \\
\hline 1980-84 & 51809.44 & 16426.78 & 31.3 & 15693.92 & 30.62 & 2618.84 & 5.15 & 7919.78 & 15.30 & 9150.94 & 17.64 \\
\hline $1985-89$ & 119632.2 & 44270.86 & 38.12 & 39978.72 & 30.85 & 2389.7 & 2.13 & 17321.90 & 14.24 & 15671.10 & 14.66 \\
\hline 1990-94 & 539207.3 & $\begin{array}{l}181622.3 \\
2\end{array}$ & 32.55 & 218568.7 & 42.27 & 6740.9 & 1.33 & 79833.92 & 14.17 & 52441.58 & 9.686 \\
\hline 1995-99 & 2668070 & $\begin{array}{l}920018.0 \\
8 \\
\end{array}$ & 34.32 & 1088922.0 & 41.19 & 20201.52 & 0.75 & 390692.2 & 14.60 & 248236.50 & 9.144 \\
\hline 2000-04 & 7223539 & $\begin{array}{l}2734641 . \\
3\end{array}$ & 37.05 & 2784781.0 & 39.38 & 68863.46 & 0.88 & 869838.4 & 12.03 & 765414.90 & 10.66 \\
\hline 2005-09 & $\begin{array}{l}2056063 \\
0\end{array}$ & $\begin{array}{l}6929310 . \\
4\end{array}$ & 33.50 & 7872204.0 & 38.71 & 277370.9 & 1.36 & $\begin{array}{l}3049964 . \\
0\end{array}$ & 14.66 & $\begin{array}{l}2431781.0 \\
0\end{array}$ & 11.76 \\
\hline $\begin{array}{l}2010- \\
12^{*}\end{array}$ & $\begin{array}{l}3712938 \\
6.5\end{array}$ & $\begin{array}{l}1236889 \\
8.7\end{array}$ & 37.02 & 16109554 & 38.3 & 212695.5 & 2.14 & 5018353 & 19.095 & 8584138 & 28. \\
\hline
\end{tabular}

Sources: CBN Statistical Bulletin, 2010; *NPC (2013); *CIA Factbook (2012)

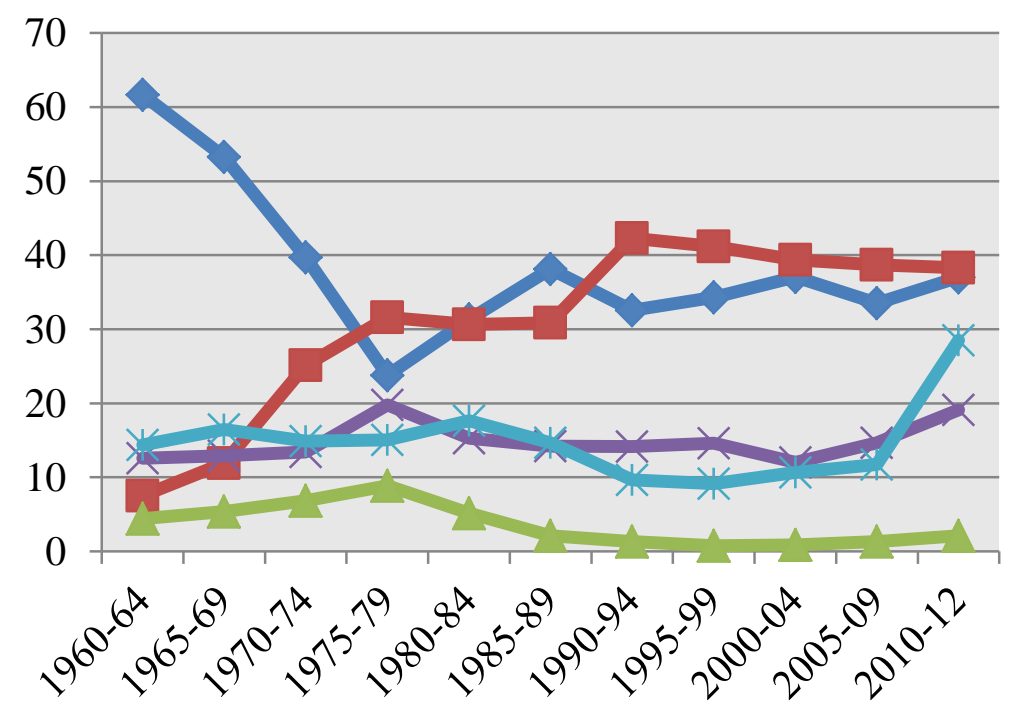

Agriculture (\%)

Industry $(\%)$

Building \& construction

$(\%)$

Wholesale \& retail

Trade $(\%)$

Fig 1: Percentage contributions of agriculture and other sectors to the GDP (1960-2012) 
Regression Analysis: Table 2 presents the result of the regression analysis using Double_Log model. The results indicate that both the coefficient of agriculture and industrial sector are statistically significant at 5 percent level as indicated by the probability values of 0.003 and 0.037 , respectively. This implies that a percentage increase in the contribution of agriculture will increase the GDP by 66.4 percent, higher than other individual sectors, which is consistence to a priori expectation. The positive relationship and statistically significance of agriculture to GDP according to Anyanwu et al (2013) is not surprising. This assertion confirmed the results of Umaru and Zubairu (2012) and Kola (2011) who variously affirmed the dominance of agriculture's contribution to GDP of Nigeria.

The $\mathrm{R}^{2}$ of 0.990 implies that 99.0 percent of total variance in GDP is explained by the regression equation or by the contributing sectors put together. Coincidentally, the goodness of fit of the regression remained high after adjusting for the degrees of freedom as indicated by the adjusted $\mathrm{R}^{2}\left(\mathrm{R}^{2}=0.989\right.$ or $\left.98.9 \%\right)$. F-statistics 873.253 , which is the measure of the joint significance of the explanatory variables, is found to be statistically significant at 5 percent as indicated by the corresponding probability value $(0.000)$.

Table 2: Parameters of regression results of agriculture and other components of the GDP against total

\begin{tabular}{|c|c|c|c|}
\hline & & GDP & \\
\hline Variables & Coefficients & t-statistics & Sig. \\
\hline (Constant) & - & 3.198 & $.003^{* * *}$ \\
\hline Agriculture & .664 & 3.313 & $.002 * *$ \\
\hline Industry & .347 & 2.147 & $.037 * *$ \\
\hline Building \&Constr & .094 & .750 & .458 \\
\hline Wholesale \&retail & -.053 & -.191 & .849 \\
\hline Services & -.052 & -.176 & .861 \\
\hline $\mathrm{R}$-square & 0.990 & & \\
\hline Adjusted R-Square & 0.989 & & \\
\hline F-statistic & 873.253 & $.000 *$ & \\
\hline
\end{tabular}

\section{Conclusion and Recommendations:}

The attainment of the transformation agenda and the envisaged Vision 20:2020 of Nigeria to a large extent depends on the development of key economic sectors that determine the growth of the Nigerian economy of which, the agricultural sector has consistently proven to hold the potentials. The empirical evidence from this study has once confirmed that the old-age advocacy for agriculture in economic development is not in any way misleading. The results affirmed the overall dominance of agriculture with clear evidence from 1960-1975, 1982-1988, 1994, 1998, 2002-03 and 2009. This result is affirmed by the regression analysis where it is clearly shown that agriculture contributes more to the nation's GDP with a coefficient of $0.664(66.40 \%)$. The study thus recommends, government should create an enabling environment by increasing the budgetary allocation, friendly policies framework for strong and efficient agricultural sector that can accelerate the attainment of Nigeria's dream of achieving the targeted growth rate and the proposed vision of becoming one among the 20 world leading economies by the year 2020 .

\section{References}

[1]. Abayomi, O. (1997). "The agricultural sector in Nigeria: The way forward." CBN Bullion, 21: 14-25.

[2]. Andohol, J. (2012). Nigeria's Food Security Programs: Implications for MDG's Goal of Extreme Hunger Eradication, International Journal of Business and Social Science 3 (9): 243.

[3]. Anyanwu, S.O., U.S. Offor., O.M.Adesope and Ibekwe U.C. (2013). Structure and growth of the GDP (1960-2008): implication for Small and Medium Enterprises in Nigeria, Global Advanced Research Journal of Management and Business Studies.2(6): 342348.

[4]. Azih, I. (2011). A background analysis of the Nigerian agricultural sector (1998 to 2007) (I)

Tuesday, 30 August 2011.

[5]. CBN (2010). Central Bank of Nigeria: Statistical Bulletin, 2010 Edition

[6]. Ehigiamusoe, U.K (2012). A Comparative Analysis of Agricultural performance between the Military and Civilian Regimes in Nigeria.International Journal of Humanities and Social Science Intervention. 1 (1): 13-23.

[7]. Ekpo, A.H. and O. J. Umoh (2012).Overview of the Nigerian Economic Growth and Development.

[8]. Ekundare, R.O. (1973). An economic history of Nigeria: 1860-1960. Africana Publishing Company. New.

[9]. FGN (2009). Report of the Vision 2020 National Technical Working Group on Agriculture and Food Security, July 2009.

[10]. FGN (2011). The Transformation Agenda (2011-2015)

[11]. Kola, D. (2001). "Non-oil Exports' Promotion: Concepts, Issues andProspects" Bullion Publication of Central Bank of Nigeria, 25 (3): $32-38$.

[12]. Muhammad, L.A., and O.AAtte (2006).Analysis of Agricultural production in Nigeria. African Journal of General Agriculture, 2(1):

[13]. Muroi, (1989), Naijeria-in-okeru-Nohgyo-Kaihuta-Seisaku in Yoshida, M.(ed) 80-nen-ndai-afurikashokoku-no-keizai-kiki-tokaichatsu-seisaku- (in English: Economic Crisis and Development Policies in African States in 1980s) Institute of Development Economics (I.D.E.) Tokyo.

[14]. Oji-Okoro, I. (2011). "Analysis of the contribution of agricultural sector on the Nigerian Economic Development."World Review of Business Research.1(1): $191-200$. 
[15]. Okolo, D. A. (2004)."Regional Study on Agricultural Support: Nigeria's Case,” being Special Study Report prepared for Food and Agricultural Organization (FAO).

[16]. Oni, O, E.,Nkonya, J., Pender, D., Philips and Kato, E (2009).Trends and drivers of Agricultural productivity in Nigeria.Nigeria Strategy Support Program (NSSP) Report 001, IFPRI-Abuja, Dec. 2009 Pp 34.

[17]. Sekumade, A.B (2009). The Effects of Petroleum dependency on Agricultural trade in Nigeria: An Error Correlation Modeling (ECM) approach, Scientific Research and Essay. 4 (11): 1385-1391.

[18]. Shimada S. (1999), A Study of Increased Food Production in Nigeria" The effect of the Structural Adjustment program on the local level."'Graduate School of Asian and African Area Studies, Kyoto University.

[19]. Suleiman, G.P. and Aminu, U. (2010).Analysis of the Contribution of the three Key sectors(Agriculture,Petroleum and Manufacturing) of the Nigerian economy.Journal of Management Studies.3. UsmanDanfodio University,Sokoto.

[20]. Udoh, E.J. (2000). Land management and resource-use efficiency among farmers in South-Eastern Nigeria.Unpublished PhD thesis, Department of Agricultural Economics University of Ibadan.

[21]. Umaru, Aminu and A. A. Zubairu (2012). An Empirical Analysis of the Contribution of Agriculture and Petroleum Sector to the Growth and Development of the Nigerian Economy from 1960-2010, International Journal of Social Science and Education.2(4): 12. 